\title{
Managerial Resourcefulness in School Administrators: Association with Stress and Depression
}

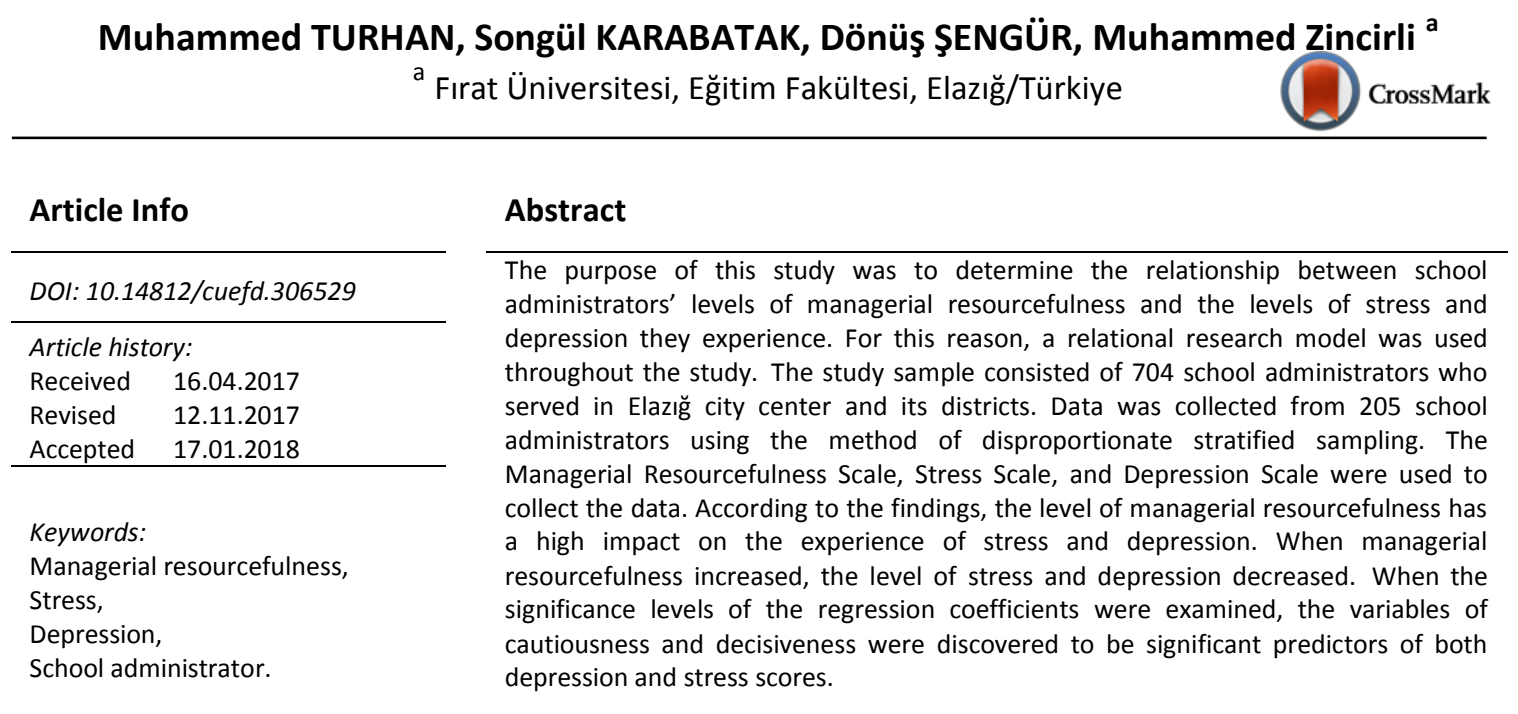

\section{Okul Yöneticilerinde Yönetsel Güçlülük: Stres ve Depresyon ile Illişkisi}

\begin{tabular}{l} 
Makale Bilgisi \\
\hline DOl: $10.14812 /$ cuefd.306529 \\
\hline Makale Geçmişi: \\
Geliş $\quad 16.04 .2017$ \\
Düzeltme 12.11 .2017 \\
Kabul $\quad 17.01 .2018$ \\
\hline \\
Anahtar Kelimeler: \\
Yönetsel güçlülük, \\
Stres, \\
Depresyon, \\
Okul yöneticisi. \\
\hline
\end{tabular}

Öz

\begin{abstract}
Bu çalışmanın amacı, okul yöneticilerinin yönetsel güçlülük düzeyleri ile yaşadıkları stres ve depresyon arasındaki ilişkiyi belirlemektir. Bu nedenle çalışmada ilişkisel araştırma modeli kullanılmıştır. Araştırmanın çalışma evrenini 2014-2015 eğitimöğretim yılında Elazığ il merkezinde ve ilçelerinde görev yapan 704 okul yöneticisi oluşturmaktadır. Çalışma kapsamında oransız eleman örnekleme yöntemi ile 205 okul yöneticisinden veriler toplanmıştır. Verilerin toplanmasında "Yönetsel Güçlülük Ölçeği”, "Stres Ölçeği” ve Depresyon Ölçeği kullanılmıştır.

Araştırma bulgularına göre; yönetsel güçlülüğün, stres ve depresyon üzerindeki etkilerinin yüksek düzeyde olduğu ve okul yöneticilerinin yönetsel güçlülük düzeyleri arttıkça, stres ve depresyon düzeylerinin azaldığı sonucuna ulaşılmıştır. Regresyon katsayılarının anlamlılık düzeyleri incelendiğinde temkinli ve tedbirli olma ile azimli olma değişkenlerinin, hem depresyon puanlarının hem de stres puanlarının anlamlı bir yordayıcısı olduğu görülmüştür.
\end{abstract}

\section{Introduction}

The work of school administrators is necessary to enable schools to fulfill their educational function efficiently. Managing schools that have to function in an ever-changing environment, and often under the influence of various pressure groups, requires different skills and competencies. Therefore, school administrators are expected to have certain characteristics other than a knowledge of regulations and managerial routines. According to Kanungo and Misra (1992), observable administrator behaviors are adequate to accomplish the routine work within an organization. However, managerial competences are necessary for more complex managerial work. Managerial resourcefulness is a concept arising from the 
need to define a field of managerial competencies. The school administrator responsible for the fulfillment of managerial processes in a school may encounter various difficulties while performing this duty. Sustaining schools amid constantly changing and developing conditions is a demonstrable example of these difficulties. Managerial resourcefulness consists of all the knowledge, skills, abilities, and competencies that administrators need to possess to resolve problems and cope with difficulties that arise in the course of their duties. Managerial resourcefulness can be defined as the administrative skills needed to control and adjust emotional reactions, cognitive views and beliefs, expectations, and behaviors that may present an obstacle to the achievement of the organization's goals and objectives or to one's successful adaptation to the environment. These skills are defined as visible behaviors specific to a particular duty and suitable for daily or programmed work. However, competencies refer to the use of intelligence and abilities in order to deal with cognitive activities involving human attitudes, which are necessary to navigate a complex and changing environment, as well as unprogrammed non-daily work (Kanungo \& Misra, 1992). When assessed in terms of school management, the behaviors that administrators must demonstrate when performing routine work can be defined as managerial skills, whereas the abilities necessary to navigate non-routine and more complex situations refer to their managerial resourcefulness. The concept of managerial resourcefulness comprises all the emotional, cognitive and behavioral skills that enable a school administrator to cope with any problem that he/she may encounter, and that enables them to adapt to the environment. According to this view, it can be concluded that managerial resourcefulness is an important component of a school administrator's leadership capacity (Kanungo \& Misra, 2005; Doğan \& Şahin, 2011).

The school administrators' problem-solving, critical, and analytical thinking skills are very important for resolving problems and demonstrating efficient managerial resourcefulness. These behaviors are a requirement of any school administrator and also consist of their managerial resourcefulness, in a sense. An administrator can be successful when they can draw upon these resources and competencies to deal with organizational problems. An administrator with high managerial resourcefulness is expected to achieve an organization's objectives efficiently, and those lacking such resourcefulness will be less able to do so. A successful administrator can be described as a person who adjusts his/her behavior in order to overcome difficult situations, using his/her competencies (Aycan, 1997). Competence can be defined as the totality of actions that administrators or workers in organizations deploy to fulfill organizational and individual objectives, using their knowledge, skills, and attitudes (Barutçugil, 2002). Managerial resourcefulness consists of certain competencies that are required by managerial work. When conceptualized in this way, managerial competencies are the major characteristics of a successful administrator. Successful administrators are those who can adjust their emotions, cognition, and behavioral tendencies to be in line with the requirements of their work (Kanungo \& Menon, 2004).

Although managerial resourcefulness is a significant leadership characteristic, there are a limited number of research studies about this topic in the literature. The insufficient number of correlation studies about this topic means there is little evidence of the individual and organizational variables that contribute to managerial resourcefulness. However, the research on learned resourcefulness, which is associated with managerial resourcefulness, provides some indications of the individual variables associated with this concept. All the research investigating learned resourcefulness demonstrates that there is a significant relationship between the level of learned resourcefulness, job stress (Akgün \& Ciarrochi, 2000; Yürür \& Keser, 2008; Yıldırım, Gülpınar and Uğuz, 2012) and depression (Chung et al., 2012). On the basis of these findings, stress can be defined as the individual's experience of exceeding their physical and psychological limits owing to unsuitable conditions in the physical and social environment (Cüceloğlu, 1994). Stress is a concept associated with managerial resourcefulness. Depression refers to a state of psychological and physical exhaustion due to a genetic, environmental or hormonal disorder. A depressed individual isn't able to continue working, their communication with the social environment breaks down, and they become more introverted (Baltaş \& Baltaş, 1998; Sezer, 2011). 
A school administrator is responsible for managing a complex organization influenced by many internal and external factors, and he/she must make many critical decisions. The administrator must refer to existing regulations to manage the school and make effective decisions that satisfy the expectations of teachers, students, and parents. Therefore, he/she should possess not only the technical knowledge and skills required to manage a school but also the competencies needed to adjust his/her cognition, perceptions and behavior to adapt to environmental pressure and demands. These competencies, defined as managerial resourcefulness, will have an impact on the emotions of school administrators. Therefore, research is needed to identify the variables that comprise managerial resourcefulness in school administrators in order to contribute to the existing literature.

The Purpose of the Research

This research aims to define the relationship between school administrators' managerial resourcefulness and the levels of stress and depression they experience. To that end, this research has tried to answer the following questions according to school administrators' perceptions:

1. What are the relationships between levels of managerial resourcefulness and stress, depression and demographic variables?

2. Is managerial resourcefulness a significant predictor of school administrators' stress levels?

3. Is managerial resourcefulness a significant predictor of school administrators' depression levels?

\section{Methods}

\section{Research Model}

A relational research model has been adopted in this study. This research investigates the possible relationships between two or more variables in the study to be conducted. A relational research model is the most appropriate for such studies (Creswell, 2012, p. 337). Relational research consists of studies that investigate the possible relationships between two or more variables to help explain the overall findings and reach a conclusion (Büyüköztürk, Çakmak, Akgün, Karadeniz \& Demirel, 2011, p. 22).

\section{Research Population and Sample}

The research sample consisted of 704 school administrators, including 238 school principals, 48 head assistant principals and 418 assistant principals, working in the city center and districts of Elazığ during the academic year of 2014-2015. The scope of this research involved collecting data from 205 school administrators, using disproportionate stratified sampling. This method is a type of sampling that ensures all elements of the population have an equal chance of being selected (Karasar, 2008, p. 113). This research sampling method represents the overall research population with a $4.84 \%$ error rate and a $90 \%$ reliability level. The demographic features of the school administrators that comprise the research sample are presented in Table 1.

Table 1.

The Demographic Features of the School Administrators Working in the City of Elazığ

\begin{tabular}{|c|c|c|c|c|c|}
\hline \multicolumn{2}{|c|}{ Demographic Features } & \multirow{2}{*}{$\frac{\mathbf{N}}{19}$} & \multicolumn{2}{|c|}{ Demographic Features } & \multirow{2}{*}{$\frac{\mathbf{N}}{15}$} \\
\hline Gender & Woman & & \multirow{8}{*}{ Type of school } & Kindergarten & \\
\hline Gernder & Man & 186 & & Primary school & 57 \\
\hline \multirow{2}{*}{ Marital status } & Married & 188 & & Secondary school & 46 \\
\hline & Single & 17 & & Common high school & 9 \\
\hline \multirow{2}{*}{ Position } & Principal & 58 & & Anatolian high school & 29 \\
\hline & Assistant principal & 147 & & Science high school & 4 \\
\hline \multirow{2}{*}{$\begin{array}{l}\text { Type of } \\
\text { appointment }\end{array}$} & Permanent & 171 & & Vocational high school & 30 \\
\hline & Substitute & 34 & & Other & 15 \\
\hline
\end{tabular}


As seen in Table 1, the administrators that participated in this research comprised 19 women and 186 men; 188 were married and 18 were single; 58 were school principals and 147 were assistant principals by position; and 171 were permanent, whereas 34 were substitute administrators by appointment. The administrators were employed in different types of schools as follows: 15 administrators worked in kindergartens, 57 in primary schools, 45 in secondary schools, 9 in common high schools, 29 in Anatolian high schools, 4 in science high schools, 30 in vocational high schools and 15 in another type of school.

\section{Collection and Analysis of Data}

The following scales were used to collect the data required: the Managerial Resourcefulness Scale, which was developed by Kanungo and Menon (2004) and translated by Ersözlü (2012) into the Turkish language; the Stress Scale, developed by Karakuş (2013); and the Depression Scale (Goldberg, 1999) from the International Personality Item Pool, translated by the researcher into the Turkish language.

The Managerial Resourcefulness Scale, translated by Ersözlü (2012) into the Turkish language, consists of three dimensions: task focus, equanimity, and deliberation, and perseverance. The internal consistency coefficient (Cronbach's alpha) of the scale has been calculated as 0.78 . The internal consistency coefficient (Cronbach's alpha) of the Stress Scale with four items and a single dimension has been calculated as 0.71 . The internal consistency coefficient (Cronbach's alpha) of the Depression Scale with six items and a single dimension has been calculated as 0.76 . During the research conducted, the internal consistency coefficient of the Managerial Resourcefulness Scale was calculated as 0.72, whereas that of the Stress Scale was calculated as 0.79 and that of the Depression Scale as 0.88 .

In relational research studies, the relationships between variables or group scores are defined and measured using correlational statistics. The types of analyses conducted, such as correlation and regression analyses, identify the relationships between the scores obtained from each individual, so that each variable's capacity to predict another can be discovered (Creswell, 2012). This study investigated the relationships between the school administrators' levels of managerial resourcefulness and the stress and depression that they experience. The SPSS 21 package program was used and a correlation analysis and a multiple regression analysis were conducted using data obtained from the scales. Four categorical variables (gender, marital status, position, and type of appointment) were coded as dummy variables during the correlation and multiple regression analyses. Dummy variables are those created by degrading the second variable and the following one into one variable group in order to have a two-level variable in statistics.

\section{Findings}

This section presents the data analysis and results. Firstly, a correlation analysis was conducted to identify the relationships between the levels of school administrators' managerial resourcefulness, stress, depression, and demographic variables. A correlation matrix is presented in Table 2 below, indicating the statistical relationships identified. 
Table 2.

A Correlation Matrix Indicating the Relationships between the Dimensions of the Managerial Resourcefulness Scale and Stress Scale, Depression Scale, and Demographic Variables

\begin{tabular}{|c|c|c|c|c|c|c|c|c|c|c|c|c|c|c|c|}
\hline & A & 1 & 2 & 3 & B & C & D & $E$ & $\mathbf{F}$ & $\mathbf{G}$ & $\mathrm{H}$ & $\mathbf{I}$ & J & $\mathbf{K}$ & $\mathbf{L}$ \\
\hline $\begin{array}{l}\text { A. } \\
\text { Resourcefulness }\end{array}$ & 1 & & & & & & & & & & & & & & \\
\hline 1. Task-focus & $.81^{* *}$ & 1 & & & & & & & & & & & & & \\
\hline $\begin{array}{l}\text { 2. Equanimity } \\
\text { and deliberation }\end{array}$ & $.69^{* *}$ & $.27^{* *}$ & 1 & & & & & & & & & & & & \\
\hline 3. Perseverance & $.77^{* * * 1}$ & $.44^{* * \cdots}$ & $.39^{* * * 1}$ & 1 & & & & & & & & & & & \\
\hline B. Stress & $-.37^{* *}$ & $-.19^{* *}$ & $-.35^{* *}$ & $-.35^{* *}$ & 1 & & & & & & & & & & \\
\hline C. Depression & $-.47^{* *}$ & $-.30^{* *}$ & $-.37^{* *}$ & $-.43^{* *}$ & $.68^{* *}$ & 1 & & & & & & & & & \\
\hline D. Gender & $-.28^{* *}$ & $-.23^{* *}$ & $-.17^{*}$ & $-.24^{* *}$ & .04 & $.22^{* *}$ & 1 & & & & & & & & \\
\hline E. Marital status & -.13 & $-.15^{*}$ & -.06 & -.08 & -.01 & .00 & $.19^{* * *}$ & 1 & & & & & & & \\
\hline F. Position & .08 & .12 & .03 & .02 & .10 & .02 & -.03 & -.08 & 1 & & & & & & \\
\hline $\begin{array}{l}\text { G. Type of } \\
\text { appointment }\end{array}$ & .02 & -.02 & .06 & .01 & -.13 & -.10 & $.18^{* *}$ & .10 & -.01 & 1 & & & & & \\
\hline H. Age & $-.23^{* *}$ & $-.22^{* *}$ & -.13 & $-.15^{*}$ & $-.18^{*}$ & -.02 & $.28^{* *}$ & $.21^{* *}$ & $-.15^{*}$ & .08 & 1 & & & & \\
\hline I. Tenure & $-.18^{*}$ & $-.19^{* *}$ & -.06 & -.13 & $-.22^{* *}$ & -.11 & $.25^{* *}$ & $.25^{* *}$ & $-.21^{* *}$ & $.21^{* *}$ & $.68^{* *}$ & 1 & & & \\
\hline $\begin{array}{l}\text { J. Working } \\
\text { period in school }\end{array}$ & .02 & .03 & .01 & .00 & .10 & -.04 & -.03 & .05 & .11 & -.03 & $.15^{*}$ & .04 & 1 & & \\
\hline $\begin{array}{l}\text { K. Number of } \\
\text { teachers }\end{array}$ & -.14 & $-.16^{*}$ & -.05 & -.08 & .06 & .10 & $.19^{* *}$ & $.15^{*}$ & .12 & .02 & $.36^{* *}$ & $.38^{* *}$ & $.22^{* *}$ & 1 & \\
\hline $\begin{array}{l}\text { L. Number of } \\
\text { students }\end{array}$ & -.12 & $-.16^{*}$ & -.05 & -.06 & .03 & .09 & $.20^{* *}$ & $.16^{*}$ & .10 & .03 & $.35^{* *}$ & $.37^{* *}$ & .11 & $.86^{* *}$ & 1 \\
\hline
\end{tabular}

An examination of the data in Table 2 reveals a significant and negative relationship statistically between the school administrators' managerial resourcefulness levels and the stress they experience $(r$ $=-.37 ; \mathrm{p}<.01)$. Also, there is a significant and negative covariance between the scores of the dimensions of managerial resourcefulness, including task focus $(r=-.19 ; p<.01)$, equanimity and deliberation $(r=-.35 ; p<.01)$, and perseverance $(r=-.35 ; p<.01)$. The greater the school administrators' managerial resourcefulness, the less stress they experience. The higher their stress levels, the less managerial resourcefulness they possess.

In addition, there is a significant and negative relationship statistically between the school administrators' levels of managerial resourcefulness and the depression they experience $(r=-.47 ; p<$ .01). Also, there is a significant and negative covariance between the dimensions of managerial resourcefulness, including task focus $(r=-.30 ; p<.01)$, equanimity and deliberation $(r=-.37 ; p<.01)$, and perseverance $(r=-.43 ; p<.01)$. On the basis of this finding, it can be suggested that the more the school administrators' managerial resourcefulness develops, the less vulnerable they are to depression.

An examination of the relationship between managerial resourcefulness and the demographic variables reveals that there is no relationship between managerial resourcefulness and position $(r=.08$; $p>.05)$, marital status $(r=-.13 ; p>.05)$, type of appointment $(r=.02 ; p>.05)$, working period in a school $(r=.02 ; p>.05)$, number of teachers $(r=-.14 ; p>.05)$ and number of students $(r=-.12 ; p>.05)$. Moreover, it can be concluded that there is a significant and negative relationship between managerial resourcefulness, age $(r=-.23 ; p<.01)$ and tenure $(r=-.18 ; p<.05)$. In other words, the greater the school administrator's age and professional experience, the less managerial resourcefulness they possess.

Furthermore, there is a significant and positive relationship between the school administrators' levels of depression and their gender $(r=.22 ; p<.01)$. This finding demonstrates that female administrators' experience more depression than males. However, there is no significant relationship between school administrators' experience of depression and other demographic variables, including marital status $(r=.00 ; p>.05)$, position $(r=.02 ; p>.05)$, type of appointment $(r=-.10 ; p>.05)$, age $(r=$ 
$-.02 ; p>.05)$, tenure $(r=-.11 ; p>.05)$, working period in a school $(r=-.04 ; p>.05)$, number of teachers $(r=.10 ; p>.05)$, and number of students $(r=-.09 ; p>.05)$.

The results of the multiple regression analysis to determine whether school administrators' managerial resourcefulness is a significant predictor of the stress they experience are presented in Table 3.

Table 3.

The Results of a Multiple Regression Analysis Indicating the Relationship between the School Administrators' Managerial Resourcefulness, Demographic Features, and Stress Levels

\begin{tabular}{|c|c|c|c|c|c|c|c|c|c|}
\hline $\begin{array}{l}\text { Predictor } \\
\text { Variables }\end{array}$ & $\mathbf{R}$ & $\mathbf{R 2}$ & $\begin{array}{c}\mathrm{R} 2 \\
\text { Change } \\
(\Delta \mathrm{R} 2)\end{array}$ & $\begin{array}{c}\mathbf{F} \\
\text { Change } \\
\mathbf{P}\end{array}$ & B & $\begin{array}{c}\text { Standard } \\
\text { Error }\end{array}$ & B & $\mathbf{t}$ & $\mathbf{P}$ \\
\hline Standard & & & & & 11.281 & 1.925 & & 5.867 & .000 \\
\hline Step 1 & .33 & .11 & .11 & .008 & & & & & \\
\hline Gender & & & & & 1.612 & 1.038 & .114 & 1.553 & .122 \\
\hline Marital status & & & & & .586 & 1.072 & .039 & .547 & .585 \\
\hline Position & & & & & .105 & .282 & .027 & .372 & .710 \\
\hline Type of appointment & & & & & -1.152 & .743 & -.110 & -1.550 & .123 \\
\hline Age & & & & & -.055 & .038 & -.139 & -1.444 & .150 \\
\hline Tenure & & & & & -.076 & .040 & -.191 & -1.897 & .059 \\
\hline Working period in school & & & & & .006 & .005 & .091 & 1.259 & .210 \\
\hline Number of teachers & & & & & .023 & .020 & .165 & 1.162 & .247 \\
\hline Number of students & & & & & .000 & .001 & -.039 & -.279 & .780 \\
\hline Step 2 & .55 & .30 & .19 & .000 & & & & & \\
\hline Task-focus & & & & & -.067 & .060 & -.079 & -1.112 & .267 \\
\hline $\begin{array}{l}\text { Equanimity and } \\
\text { deliberation }\end{array}$ & & & & & -.280 & .076 & -.247 & -3.671 & .000 \\
\hline Perseverance & & & & & -.303 & .084 & -.262 & -3.621 & .000 \\
\hline
\end{tabular}

According to the data presented in Table 3, the variables of gender, marital status, position, type of appointment, age, tenure, working period in a school, and number of teachers and students, which were involved in the analysis at the first step, were a significant predictor of the stress experienced by school administrators $(\triangle R 2=0.11 ; p<.01)$. However, when examining the significance levels of the regression coefficients of the variables mentioned, no single variable was a significant predictor of stress scores.

The variables of task focus, equanimity and deliberation, and perseverance, which are the three dimensions of managerial resourcefulness involved in the analysis at the second step, were a significant predictor of stress scores $(\Delta R 2=.19, p<.01)$. Also, when the significance levels of the regression coefficients are examined, the variables of equanimity and deliberation $(\beta=-.25 ; p<.01)$ and perseverance $(\beta=-.26 ; p<.01)$ were significant predictors of stress scores. However, the variable of task focus was not a significant predictor of stress scores $(\beta=-.07 ; p>.01)$. Checking the effects of other variables, it can be suggested that $19 \%$ of the stress experienced by the school administrators results from a lack of managerial resourcefulness. In other words, it can be concluded that the greater the administrators' managerial resourcefulness, the less stress they experience.

The results of the multiple regression analysis to determine whether school administrators' levels of managerial resourcefulness are significant predictors of the depression they experience are presented below in Table 4. 
Table 4.

The Results of a Multiple Regression Analysis Indicating the Relationship between School Administrators' Levels of Managerial Resourcefulness, Demographic Features, and Depression Levels

\begin{tabular}{|c|c|c|c|c|c|c|c|c|c|}
\hline $\begin{array}{l}\text { Predictor } \\
\text { Variables }\end{array}$ & $\mathbf{R}$ & R2 & $\begin{array}{c}\text { R2 } \\
\text { Change } \\
(\Delta R 2)\end{array}$ & $\begin{array}{c}\text { F } \\
\text { Change } \\
\text { P }\end{array}$ & B & $\begin{array}{c}\text { Standard } \\
\text { Error }\end{array}$ & B & $\mathbf{t}$ & $\mathbf{P}$ \\
\hline Standard & & & & & 9.639 & 2.681 & & 3.595 & .000 \\
\hline Step 1 & .32 & .10 & .101 & .014 & & & & & \\
\hline Gender & & & & & 5.068 & 1.446 & .257 & 3.504 & .001 \\
\hline Marital status & & & & & -.151 & 1.493 & -.007 & -.101 & .920 \\
\hline Position & & & & & -.097 & .393 & -.018 & -.248 & .804 \\
\hline Type of appointment & & & & & -1.630 & 1.035 & -.112 & -1.574 & .117 \\
\hline Age & & & & & .004 & .053 & .008 & .081 & .936 \\
\hline Tenure & & & & & -.110 & .056 & -.198 & -1.961 & .051 \\
\hline $\begin{array}{l}\text { Working period in } \\
\text { school }\end{array}$ & & & & & -.005 & .007 & -.049 & -.683 & .495 \\
\hline Number of teachers & & & & & .024 & .027 & .126 & .889 & .375 \\
\hline Number of students & & & & & $6.652 \mathrm{E}-5$ & .001 & .007 & .049 & .961 \\
\hline Step 2 & .56 & .31 & .212 & .000 & & & & & \\
\hline Task-focus & & & & & -.149 & .082 & -.127 & -1.809 & .072 \\
\hline $\begin{array}{l}\text { Equanimity and } \\
\text { deliberation }\end{array}$ & & & & & -.340 & .105 & -.216 & -3.243 & .001 \\
\hline Perseverance & & & & & -.453 & .115 & -.282 & -3.927 & .000 \\
\hline
\end{tabular}

An examination of the data presented in Table 4 revealed that a significant relationship existed between depression and the variables of gender, marital status, position, type of appointment, age, tenure, working period in a school, and number of teachers and students, which were involved in the analysis at the first step $(\triangle \mathrm{R} 2=.101, \mathrm{p}<.05)$. However, when the significance levels of regression coefficients were examined, gender was the only variable that was a significant predictor of depression $(\beta=-.26 ; p<.01)$. All other variables did not possess any explanatory power for depression. In addition, the variables of task focus, equanimity and deliberation, and perseverance, which are the three dimensions of managerial resourcefulness and were involved in the analysis at the second step, were all significant predictors of depression scores $(\Delta R 2=.21, p<.01)$. However, on the basis of the significance levels of the regression coefficients, the variables of equanimity and deliberation $(\beta=-.22, p<.01)$ and perseverance $(\beta=-.28, p<.01)$ were significant predictors of depression scores. According to this finding, $21 \%$ of the depression that school administrators' experience results from a lack of managerial resourcefulness. In other words, the greater the administrators' levels of managerial resourcefulness, the less depression they experience.

\section{Conclusion, Discussion, and Suggestions}

According to the findings obtained above, there is a significant and negative relationship statistically between the total scores of managerial resourcefulness and the scores of its dimensions (including task focus, equanimity and deliberation, and perseverance) and stress and depression scores. Therefore, the greater the school administrators' managerial resourcefulness, the less stress and depression they experience.

The findings obtained from the multiple regression analysis discovered that after controlling the personal and demographic variables (gender, marital status, position, type of appointment, age, professional experience, and number of teachers and students in a school), managerial resourcefulness is a significant predictor of stress and depression. The studies conducted by Kanungo and Menon (2004, 2005) demonstrated that managerial resourcefulness has a positive relationship with psychological strengthening and a negative relationship with learned helplessness. The findings obtained from this 
research parallel those of research investigating learned resourcefulness and learned helplessness, which are closely associated with managerial resourcefulness (Yıldırım et al., 2012; Akgün \& Ciarrochi, 2000; Chung et al., 2012). Learned resourcefulness is similar to managerial resourcefulness and is an important component of stress endurance. Studies investigating this topic demonstrate that learned resourcefulness consists of cognitive structures termed "coping skills," which are essential to manage stress (Öztaykutlu, 2014). Meichenbaum (1977), who first coined the term "learned resourcefulness," stated that it consists of certain auxiliary attitudes that help one to cope with external stress factors and to control problematic and stressful life events. Moreover, a study conducted by Eroğlu, Akbaba, Adigüzel and Peker (2014) demonstrated that there are significant relationships between learned resourcefulness and stress management. In their study, Yürür and Keser (2010) suggested that learned resourcefulness is a significant personal trait that enables school teachers experiencing professional stress to protect themselves from it. In a study conducted by Yıldıım et al. (2012), a positive and poor relationship was discovered between two dimensions of learned resourcefulness and dimensions of work-related stress, including pressure, and overloading.

According to the findings of this research, there is a significant relationship between managerial resourcefulness, stress, and depression. An examination of the significance levels of the regression coefficients revealed that the variables of equanimity and deliberation, as well as perseverance, are significant predictors of stress and depression scores. School administrators' successful work performance is of great importance because they have a leading role at every stage of the school management process. Successful work performance is related to an administrator's ability to manage this process with perseverance and decisiveness. Hence, the presence of skills in many fields, such as problem-solving, decision-making, planning, orientation, crisis management, communication, and change management, are considered indicators of managerial resourcefulness (Knungo \& Menon, 2004). For instance, school administrators make decisions by considering the multiple factors needed to perform their duties, including planning and the management of organizational resources. Their thinking processes must remain task-focused, yet they must also consider the effect of decisions that they make on other people and persevere when implementing those decisions. Therefore, school leaders may sometimes experience high stress levels and depressive symptoms. When selecting and appointing an administrator, assessing their managerial resourcefulness in terms of competencies would make a useful contribution to the recruitment process.

In the light of these conclusions, it is possible to make the following suggestions:

- When selecting and training school administrators, candidates' managerial resources should be assessed alongside their behavior. Also, trainings and seminars on managerial resourcefulness would be beneficial, provided that they are offered early in the selected administrators' tenure.

- Current working conditions make it impossible to prevent stress and the potential for depressive tendencies to arise. According to this research, developing school administrators' levels of managerial resourcefulness can help to prevent stress and depressive symptoms. Therefore, policymakers should consider training school administrators in managerial resourcefulness in order to improve their working conditions.

- Training school administrators should involve acquiring managerial resourcefulness through methods such as sensitivity training.

- There may be many emotional states, attitudes, and behaviors that act as precursors or outcomes of managerial resourcefulness. On the basis of the existing literature, it should be possible to identify the emotional states, attitudes, and behaviors that may affect school administrators' managerial resourcefulness and to conduct further research studies on the relationships between them. 


\section{Türkçe Sürümü}

\section{Giriş}

Okulların eğitim-öğretim işlevini etkili şekilde yerine getirebilmesinde okul yöneticilerinin çabaları büyük önem taşımaktadır. Değişen çevrenin ve farklı baskı gruplarının etkisi altında çalışmak zorunda olan okulları yönetmek farklı yetenek ve yeterliklere sahip olmayı gerektirmektedir. Bu nedenle, okul yöneticilerinden, mevzuata ilişkin bilgiler ve yönetsel rutinlerin ötesinde başka özellikler de beklenmektedir. Kanungo ve Misra'ya (1992) göre; gözlemlenebilir yönetici davranışları örgüt içindeki rutin işleri başarmak için yeterlidir. Ancak, daha karmaşık yönetsel işler için yönetsel yeterliklere ihtiyaç vardır. Yönetsel güçlülük de böyle bir yeterlik alanını tanımlama ihtiyacından doğmuş bir kavramdır. Okuldaki yönetim süreçlerinin gerçekleşmesinden sorumlu olan yönetici, bu görevini yerine getirirken pek çok zorluk ile karşılaşabilir. Özellikle değişen ve gelişen günümüz şartlarına göre okulu ayakta tutmayı bu duruma örnek gösterebiliriz. Her çeşit engel ve zorlukla baş edebilmek için yöneticilerin sahip olduğu bilgi, beceri, yetenek ve yeterliliklerin tümü yönetsel güçlülüğü oluşturur. Yönetsel güçlülük, yöneticinin organizasyonun belirlenen amaç ve hedeflerine ulaşmasında engel teşkil edebilecek her türlü duygusal tepkilerini, bilişsel düşüncelerini ve inançlarını, beklentilerini, davranışlarını kontrol edebilme ve düzenlemesiyle çevreye başarılı uyum sağlamada edinilmiş yetenekler birikimi olarak tanımlanabilir. Bu yönüyle beceriler, günlük veya programlanmış işlere uygun, göreve özgü, göz önünde olan davranışlar olarak tanımlanırken; buna karşılık yeterlikler; karmaşık, değişken bir çevre ve programlanmamış, günlük olmayan işler için gerekli insana özgü genel tavırları içeren bilişsel etkinliklerle ilgilenmek için zekânın kullanımına ve yeteneklere işaret eder (Kanungo ve Misra, 1992). Okul yönetimi açısından değerlendirildiğinde, yöneticilerin okuldaki rutin işleri gerçekleştirebilmek için ihtiyaç duydukları davranışlar yönetsel beceriler olarak açıklanırken, rutin olmayan ve daha karmaşık bir durumda karar verebilmek için gerekli yetenekler yönetsel güçlülük kavramı ile açıklanmaktadır. Yönetsel güçlülük kavramı, bir okul yöneticisinin karşılaşabileceği her türlü sorunla başa çıkmasını ve çevreye uyumunu sağlayan duygusal, zihinsel ve davranışsal yetenekler bütünüdür. Buradan, yönetsel güçlülüğün, okul yöneticilerinin liderlikle ilgili niteliklerinin önemli bir bileşeni olduğu sonucuna ulaşılmaktadır (Kanungo ve Misra, 2005; Doğan ve Şahin, 2011).

Okul yöneticilerinin sahip oldukları problem çözme, eleştirel ve analitik düşünme becerileri, sorunları çözmek ve etkili bir yönetimsel güç sergilemek için önem arz etmektedir. Bu davranışlar, okul yöneticilerinin sahip olması gereken yeterliklerdendir ve bir bakıma yönetsel güçlerini de ifade eder. Yönetici bu güç ve yeterliklerini sorunlarla baş etmede kullanabildiği ölçüde başarılı olabilir. Yönetsel gücü yüksek olan bir yöneticinin örgütün amaçlarına ulaşmasında daha başarılı olacağı beklenirken aksi durumda ise yöneticinin amaçlara hizmet etme derecesinin daha düşük olacağı söylenebilir. Başarılı yönetici, sahip olduğu yeterlikler ile zor durumların üstesinden gelebilmek için davranışlarını düzenleyen kişi olarak nitelendirilir (Aycan, 1997). Yöneticilerin veya örgütlerdeki işgörenlerin sahip oldukları bilgi, beceri ve tutumları kullanarak örgütsel ve bireysel düzeyde belirlenen hedeflere ulaşmak için gerçekleştirdikleri eylemlerin bütünü yeterlilik olarak görülür (Barutçugil, 2002). Yönetsel güçlülük, yönetsel işlerin gerekliliklerine cevaplar verebilen birtakım genel yeterliklerdir. Bu yolla kavramsallaştırılmış olarak, yönetsel yeterlikler başarılı bir yöneticinin temel özelliğidir. Başarılı yöneticiler; duygularını, bilişlerini ve davranışsal eğilimlerini işin taleplerine uygun olarak düzenleyenlerdir (Kanungo ve Menon, 2004).

Yönetsel güçlülük, önemli bir liderlik özelliği olmasına karşın, konu hakkında literatürde sınırlı sayıda araştırma yer almaktadır. Özellikle, konu ile ilgili korelasyonel çalışmaların yetersiz olması, yönetsel güçlülüğün hangi bireysel ve örgütsel değişkenlerle ilişkili olduğunu anlamamız güçleştirmektedir. Ancak, yönetsel güçlülükle ilişkili olan öğrenilmiş güçlülük ile ilgili yapılmış çalışmalar, yönetsel güçlülüğün bireysel sonuçları ile ilgili fikir vermektedir. Yapılan araştırmalar, öğrenilmiş güçlülük düzeyi ile iş stresi (Akgün ve Ciarrochi, 2000; Yürür ve Keser, 2008; Yıldırım, Gülpınar ve Uğuz, 2012) ve 
depresyon (Chung ve diğerleri, 2012) arasında anlamlı ilişkinin olduğunu göstermektedir. Buradan bireyin fiziki ve sosyal çevredeki uyumsuz koşullar nedeniyle, bedensel ve psikolojik sınırlarının ötesinde harcadığı gayret (Cüceloğlu, 1994) olarak tanımlanan stresin de yönetsel güçlülükle ilişkili bir kavram olduğu söylenebilir. Depresyon ise, kişide kalıtımsal, çevresel ya da hormonal bozukluklar sonrasında gelişen çökkünlük hâlidir. Depresyondaki birey işine devam edememekte, sosyal çevresi ile iletişimi bozulmakta ve daha fazla içine kapanmaktadır (Baltaş ve Baltaş, 1998; Sezer, 2011).

Okul yöneticisi, birçok iç ve dış faktörün etkili olduğu karmaşık bir örgütü yönetme ve karar verme sorumluluğunu taşımaktadır. Okulu yönetmek ve etkili karar vermek için bir yandan mevzuatın gereklerini dikkate alırken bir yandan da öğretmen, öğrenci ve velilerin beklentilerini karşılamak için çaba göstermek durumundadır. Bu nedenle, okul yönetimine ilişkin teknik bilgi ve becerilerin yanında, biliş, duyuş ve davranışlarını çevresel baskı ve taleplere göre düzenlemeye ilişkin yeterliklere sahip olmalıdır. Yönetsel güçlülük olarak tanımlanan bu yeterlikler, okul yöneticilerinin duygu durumları üzerinde etkili olabilir. Bu yüzden, okul yöneticilerinin yönetsel güçlülük düzeyleri ve ilişkili olduğu değişkenler konusunda yapılacak araştırmaların ilgili alanyazına katkı sağlayacağı düşünülmektedir.

\section{Araştırmanın Amacı}

$\mathrm{Bu}$ araştırmanın amacı, okul yöneticilerinin yönetsel güçlülük düzeyleri ile yaşadıkları stres ve depresyon arasındaki ilişkiyi belirlemektir. Bu amaç doğrultusunda; okul yöneticilerinin algılarına göre aşağıdaki sorulara cevap aranmıştır:

1. Yönetsel güçlülük düzeyleri ile stres, depresyon ve demografik değişkenler arasında nasıl bir ilişki vardır?

2. Yönetsel güçlülük okul yöneticilerinin stres düzeylerinin anlamlı bir yordayıcısı mıdır?

3. Yönetsel güçlülük okul yöneticilerinin depresyon düzeylerinin anlamlı bir yordayıcısı mıdır?

\section{Yöntem}

\section{Araştırmanın Modeli}

Bu çalışmada ilişkisel araştırma modeli benimsenmiştir. Yapılacak çalışmada iki veya daha fazla değişkenin arasındaki olası ilişkileri incelemeye odaklanılmak istenebilir. Bu tür çalışmalarda ilişkisel araştırma modelinin kullanılması daha uygundur (Creswell, 2012, s. 337). Ilişkisel araştırmalar, iki ya da daha fazla değişken arasındaki olası ilişkiyi araştırarak, olguyu daha iyi açıklamayı sağlayan çalışmalardır (Büyüköztürk, Çakmak, Akgün, Karadeniz ve Demirel, 2011, s.22).

\section{Evren ve Örneklem}

Araştırmanın çalışma evrenini 2014-2015 eğitim-öğretim yılında Elazığ il merkezinde ve ilçelerinde görev yapan 238 tane okul müdürü, 48 tane müdür başyardımcısı ve 418 tane de müdür yardımcısı olmak üzere toplam 704 okul yöneticisi oluşturmaktadır. Araştırma kapsamında oransız eleman örnekleme yöntemi ile 205 okul yöneticisinden veriler toplanmıştır. Oransız eleman örnekleme yöntemi, evrendeki tüm elemanların eşit seçilme şansına sahip oldukları örnekleme türüdür (Karasar, 2008, s.113). \%4,84'lük hata ile \%90'lık güven düzeyinde örneklemin evrenin temsil ettiği görülmüştür. Araştırmanın örneklemini oluşturan okul yöneticilerinin demografik özellikleri Tablo 1'deki gibidir. 
Tablo 1.

Elazığ Ili'nde Görev Yapan Okul Yöneticilerinin Demografik Özellikleri

\begin{tabular}{|c|c|c|c|c|c|}
\hline \multicolumn{2}{|c|}{ Demografik Özellikler } & \multirow{2}{*}{$\begin{array}{c}\mathbf{N} \\
19\end{array}$} & \multicolumn{2}{|c|}{ Demografik Özellikler } & \multirow{2}{*}{$\begin{array}{c}\mathbf{N} \\
15\end{array}$} \\
\hline \multirow{2}{*}{ Cinsiyet } & Kadın & & \multirow{8}{*}{ Okul türü } & Anaokulu & \\
\hline & Erkek & 186 & & İlkokul & 57 \\
\hline \multirow{2}{*}{ Medeni durum } & Evli & 188 & & Ortaokul & 46 \\
\hline & Bekar & 17 & & Genel lise & 9 \\
\hline \multirow{2}{*}{ Görev türü } & Okul müdürü & 58 & & Anadolu lisesi & 29 \\
\hline & Müdür yardımcısı & 147 & & Fen lisesi & 4 \\
\hline \multirow{2}{*}{ Atanma şekli } & Asil & 171 & & Meslek lisesi & 30 \\
\hline & Vekil & 34 & & Diğer & 15 \\
\hline
\end{tabular}

Tablo 1'de görüldüğü gibi araştırma kapsamında yer alan yöneticilerin; 19'u kadın, 186'sı erkek; medeni durumlarına göre 188'i evli, 17'i bekâr; görev türüne göre 58'i okul müdürü, 147'si müdür yardımcısı; atanma şekline göre 171'i asil, 34'ü vekil; okul türüne göre 15'i anaokulunda, 57'si ilkokulda, 46'sı ortaokulda, 9'u genel lisede, 29'u Anadolu lisesinde, 4'ü fen lisesinde, 30'u meslek lisesinde, 15'i başka okul türünde görev yapmaktadır.

\section{Verilerin Toplanması ve Analizi}

Verilerin toplanmasında Kanungo ve Menon (2004) tarafından geliştirilen ve Ersözlü (2012) tarafından Türkçe'ye uyarlanan "Yönetsel Güçlülük Ölçeği”, Karakuş (2013) tarafından geliştirilen "Stres Ölçeği" ve Uluslararası Kişilik Madde Havuzunda yer alan ve Türkçeye uyarlaması yine araştırmacı (2013) tarafından yapılan Depresyon Ölçeği (Goldberg, 1999) kullanılmıştır.

Ersözlü (2012) tarafından Türkçe'ye uyarlanan Yönetsel Güçlülük Ölçeği üç boyuttan (görev odaklı olma, temkinli ve tedbirli olma, azimli olma) oluşmaktadır. Ölçeğin iç tutarlılık (Cronbach's Alpha) katsayısı 0.78 olarak hesaplanmıştır. Dört maddeli ve tek boyutlu bir yapıya sahip olan Stres Ölçeği'nin iç tutarlılık katsayısı (Cronbach's Alpha) 0.71 olarak hesaplanmıştır. Altı maddeli ve tek boyutlu Depresyon Ölçeği'nin iç tutarlılık katsayısı ise 0.76 olarak bulunmuştur. Yapılan çalışmada Yönetsel Güçlülük Ölçeği'nin iç tutarlık katsayısı 0.72, Stres Ölçeği'nin iç tutarlılık katsayısı 0.79 ve Depresyon Ölçeği'nin iç tutarlılık katsayısı ise 0.88 olarak hesaplanmıştır.

İlişkisel çalışmalarda, korelasyonel istatistikler kullanılarak değişkenler veya grup puanları arasındaki ilişkiler tanımlanır ve ölçülür. Korelasyon ve regresyon gibi analizler, her bireyden elde edilmiş puanlar arasındaki ilişkilerin test edilmesini ve değişkenlerin birbirlerini yordama durumlarını ortaya konmasını sağlar (Creswell, 2012). Bu çalışmada, okul yöneticilerinin yönetsel güçlülük düzeyleri ile okul yöneticilerinin yaşadıkları stres ve depresyon arasındaki ilişkilerin ortaya konması hedeflenmektedir. Bu amaçla da kullanılan ölçekler ile toplanan verilerin analizinde SPSS 21 paket programından faydalanılmış ve korelasyon analizi ile çoklu regresyon analizi yapılmıştır. Korelasyon analizi ve çoklu regresyon analizinde iki kategorili değişkenler (cinsiyet, medeni durum, görev ve atanma şekli) dummy (kukla) değişken olarak kodlanmıştır. Dummy değişkenler, istatistikte iki seviyeye sahip bir değişken oluşturmak için ikinci ve ikinciden sonra gelen değişkenlerin, bir değişken grubuna indirgenmesi durumunda oluşturulan değişkendir.

\section{Bulgular}

Bu bölümde araştırma sürecinde uygulanan ölçeklerden elde edilen veriler analiz edilerek sunulmuştur. Bu nedenle ilk olarak okul yöneticilerin yönetsel güçlülük düzeyleri ile stres, depresyon ve demografik değişkenler arasındaki ilişkiyi belirlemek amacıyla korelasyon analizi yapılmıştır. Okul yöneticilerinin yönetsel güçlülük düzeyleri ile stres, depresyon ve demografik değişkenler arasındaki ilişkiyi gösteren korelasyon matrisi Tablo 2'de verilmiştir. 
Tablo 2.

Yönetsel Güçlülük Ölçeğinin Boyutları, Stres Ölçeği, Depresyon Ölçeği ve Demografik Değişkenler Arasındaki iliş̧kiyi Gösteren Korelasyon Matrisi

\begin{tabular}{|c|c|c|c|c|c|c|c|c|c|c|c|c|c|c|c|}
\hline & A & 1 & 2 & 3 & B & C & D & $\mathbf{E}$ & $\mathbf{F}$ & $\mathbf{G}$ & $\mathbf{H}$ & 1 & $\mathrm{~J}$ & $\mathbf{K}$ & $\mathbf{L}$ \\
\hline A. Güçlülük & 1 & & & & & & & & & & & & & & \\
\hline $\begin{array}{l}\text { 1. Görev odaklı } \\
\text { olma }\end{array}$ & $.81^{* *}$ & 1 & & & & & & & & & & & & & \\
\hline $\begin{array}{l}\text { 2. Temkinli \& } \\
\text { tedbirli olma }\end{array}$ & $.69^{* *}$ & $.27^{* *}$ & 1 & & & & & & & & & & & & \\
\hline 3. Azim olma & $.77^{* * *}$ & $.44^{* * \cdots}$ & $.39^{* *}$ & 1 & & & & & & & & & & & \\
\hline B. Stres & $-.37^{* *}$ & $-.19^{* *}$ & $-.35^{* *}$ & $-.35^{* *}$ & 1 & & & & & & & & & & \\
\hline C. Depresyon & $-.47^{* *}$ & $-.30^{* *}$ & $-.37^{* *}$ & $-.43^{* *}$ & $.68^{* * *}$ & 1 & & & & & & & & & \\
\hline D. Cinsiyet & $-.28 *$ & $-.23^{* *}$ & $-.17^{*}$ & $-.24 *$ & .04 & $.22^{* *}$ & 1 & & & & & & & & \\
\hline $\begin{array}{l}\text { E. Medeni } \\
\text { durum }\end{array}$ & -.13 & $-.15^{*}$ & -.06 & -.08 & -.01 & .00 & $.19^{* *}$ & 1 & & & & & & & \\
\hline F. Görev & .08 & .12 & .03 & .02 & .10 & .02 & -.03 & -.08 & 1 & & & & & & \\
\hline G. Atanma şekli & .02 & -.02 & .06 & .01 & -.13 & -.10 & $.18^{* *}$ & .10 & -.01 & 1 & & & & & \\
\hline H. Yaş & $-.23^{* *}$ & -.22 & -.13 & $-.15^{*}$ & $-.18^{*-1}$ & -.02 & $.28^{* * *}$ & $.21^{* *}$ & $-.15^{*}$ & .08 & 1 & & & & \\
\hline I. Kıdem & -.18 & $-.19^{* *}$ & -.06 & -.13 & $-.22^{* *}$ & -.11 & $.25^{* *}$ & $.25^{* * *}$ & $-.21^{* *}$ & $.21^{* * *}$ & $.68^{* * *}$ & 1 & & & \\
\hline $\begin{array}{l}\text { J. Okulda } \\
\text { çalışma süresi }\end{array}$ & .02 & .03 & .01 & .00 & .10 & -.04 & -.03 & .05 & .11 & -.03 & $.15^{*}$ & .04 & 1 & & \\
\hline $\begin{array}{l}\text { K. Öğretmen } \\
\text { sayısı }\end{array}$ & -.14 & $-.16^{*}$ & -.05 & -.08 & .06 & .10 & $.19^{* *}$ & $.15^{*}$ & .12 & .02 & $.36^{* *}$ & $.38^{* *}$ & $.22^{* *}$ & 1 & \\
\hline L. Öğrenci sayısı & -.12 & $-.16^{* *-1}$ & -.05 & -.06 & .03 & .09 & $.20^{* * *}$ & $.16^{* *}$ & .10 & .03 & $.35^{* * \cdots}$ & $.37^{* * *}$ & .11 & $.86^{* *}$ & 1 \\
\hline
\end{tabular}

Tablo 2'deki veriler incelendiğinde okul yöneticilerinin yönetsel güçlülük düzeyleri ile yaşadıkları stres arasında istatistiki olarak anlamlı ve ters yönde bir ilişkinin olduğu görülmektedir ( $r=-.37 ; p<.01)$. Ayrıca, yönetsel güçlülüğün görev odaklı olma $(r=-.19 ; p<.01)$, temkinli ve tedbirli olma $(r=-.35 ; p<.01)$ ve azimli olma ( $r=-.35 ; p<.01$ ) boyutlarının puanları ile stres düzeyi arasında anlamlı ve zıt yönde bir birlikte değişim bulunmaktadır. Okul yöneticilerinin yönetsel güçlülüğü arttıkça stres düzeyleri azalmaktadır ya da stres düzeyi arttıkça yönetsel gücü zayıflamaktadır.

Okul yöneticilerinin yönetsel güçlülük düzeyleri ile yaşadıkları depresyon arasında istatistiki olarak anlamlı ve ters yönde bir ilişkinin olduğu görülmektedir ( $r=-.47 ; p<.01)$. Ayrıca, yönetsel güçlülüğün görev odaklı olma $(r=-.30 ; p<.01)$, temkinli ve tedbirli olma $(r=-.37 ; p<.01)$ ve azimli olma $(r=-.43 ; p<.01)$ boyutları ile depresyon düzeyi arasında anlamlı ve zıt yönde bir birlikte değişim bulunmaktadır. Bu bulgudan hareketle, okul yöneticilerinin yönetsel güçlülük düzeyleri arttıkça depresyon düzeylerinin azaldığı söylenebilir.

Yönetsel güçlülük ile demografik değişkenler arasındaki ilişki incelendiğinde; yönetsel güçlülük ile görev ( $r=.08 ; p>.05)$, medeni durum ( $r=-.13 ; p>.05)$, atama şekli ( $r=.02 ; p>.05$ ), okulda çalışma süresi $(r=.02 ; p>.05)$, öğretmen sayısı ( $r=-.14 ; p>.05)$ ve öğrenci sayısı $(r=-.12 ; p>.05)$ arasında ise herhangi bir ilişkinin bulunmadığı tespit edilmiştir. Bunun yanında yönetsel güçlülük ile yaş $(r=-.23 ; p<.01)$ ve kıdem ( $r=-.18 ; p<.05)$ arasında anlamlı ve zıt yönde bir ilişkinin olduğu sonucuna ulaşılmaktadır. Yani yaş ve mesleki deneyim arttıkça, yönetsel güçlülüğün azaldığı belirlenmiştir.

Okul yöneticilerinin depresyon düzeyleri ile cinsiyet değişkeni arasında ( $r=.22 ; p<.01)$ anlamlı ve pozitif yönde bir ilişkinin olduğu görülmektedir. Bu durum bayan yöneticilerin depresyon düzeylerinin erkek yöneticilere göre daha yüksek düzeyde olduğunu göstermektedir. Diğer yandan, yöneticilerin depresyon düzeyleri ile diğer demografik değişkenler arasında [medeni durum ( $r=.00 ; p>.05)$, görev $(r=.02 ; p>.05)$, atanma şekli ( $r=-.10 ; p>.05)$, yaş ( $r=-.02 ; p>.05)$, kıdem ( $r=-.11 ; p>.05)$, okuldaki çalışma süresi ( $r=-.04 ; p>.05$ ), öğretmen sayısı $(r=.10 ; p>.05)$ ve öğrenci sayısı ( $r=-.09 ; p>.05)$ ] arasında anlamlı bir ilişkinin olmadığı görülmektedir. 
Okul yöneticilerinin yönetsel güçlülük düzeylerinin, yaşadıkları stresin anlamlı bir yordayıcısı olup olmadığını belirlemek amacıyla yapılan çoklu regresyon analizi sonuçları Tablo 3'te verilmiştir.

\section{Tablo 3.}

Okul Yöneticilerinin Yönetsel Güçlülük Düzeyleri, Demografik Özellikleri ve Stres Düzeyleri Arasındaki ilişkiyi Gösteren Çoklu Regresyon Analizi Sonuçları

\begin{tabular}{|c|c|c|c|c|c|c|c|c|c|}
\hline $\begin{array}{l}\text { Yordayıcı } \\
\text { Değişkenler }\end{array}$ & $\mathbf{R}$ & $\mathbf{R 2}$ & $\begin{array}{c}\text { R2 } \\
\text { Değişikliği } \\
(\Delta R 2)\end{array}$ & $\begin{array}{c}\mathbf{F} \\
\text { Değişikliği } \\
\text { P }\end{array}$ & B & $\begin{array}{c}\text { Standart } \\
\text { Hata }\end{array}$ & B & $\mathbf{t}$ & $\mathbf{P}$ \\
\hline Standart & & & & & 11.281 & 1.925 & & 5.867 & .000 \\
\hline Adım 1 & .33 & .11 & .11 & .008 & & & & & \\
\hline Cinsiyet & & & & & 1.612 & 1.038 & .114 & 1.553 & .122 \\
\hline Medeni Durum & & & & & .586 & 1.072 & .039 & .547 & .585 \\
\hline Görev & & & & & .105 & .282 & .027 & .372 & .710 \\
\hline Atanma Şekli & & & & & -1.152 & .743 & -.110 & -1.550 & .123 \\
\hline Yaş & & & & & -.055 & .038 & -.139 & -1.444 & .150 \\
\hline Kıdem & & & & & -.076 & .040 & -.191 & -1.897 & .059 \\
\hline Okulda çalışma süresi & & & & & .006 & .005 & .091 & 1.259 & .210 \\
\hline Öğretmen sayısı & & & & & .023 & .020 & .165 & 1.162 & .247 \\
\hline Öğrenci sayısı & & & & & .000 & .001 & -.039 & -.279 & .780 \\
\hline Adım 2 & .55 & .30 & .19 & .000 & & & & & \\
\hline Görev odaklı olma & & & & & -.067 & .060 & -.079 & -1.112 & .267 \\
\hline $\begin{array}{l}\text { Temkinli\&tedbirli } \\
\text { olma }\end{array}$ & & & & & -.280 & .076 & -.247 & -3.671 & .000 \\
\hline Azimli olma & & & & & -.303 & .084 & -.262 & -3.621 & .000 \\
\hline
\end{tabular}

Tablo 3'teki verilere göre, analize birinci adımda giren cinsiyet, medeni durum, görev, atanma şekli, yaş, kıdem, okuldaki çalışma süresi, öğretmen ve öğrenci sayılarının birlikte okul yöneticilerinin yaşadıkları stresin anlamlı bir yordayıcısı olduğu görülmektedir ( $\Delta R 2=0.11 ; p<.01)$. Ancak söz konusu değişkenlerin, regresyon katsayılarının anlamlılık düzeyleri incelendiğinde, hiçbir değişkeninin, stres puanlarının anlamlı bir yordayıcısı olmadığı anlaşılmaktadır.

Analize ikinci adımda giren ve yönetsel güçlülüğün boyutları olan görev odaklı olma, temkinli ve tedbirli olma, azimli olma değişkenlerinin stres puanlarının anlamlı bir yordayıcısı olduğu görülmektedir $(\Delta \mathrm{R} 2=.19, \mathrm{p}<.01)$. Ayrıca, regresyon katsayılarının anlamlılık düzeyleri incelendiğinde temkinli ve tedbirli olma $(\beta=-.25 ; p<.01)$ ile azimli olma $(\beta=-.26 ; p<.01)$ değişkenlerinin, stres puanlarının anlamlı bir yordayıcısı olduğu anlaşılmaktadır. Ancak, görev odaklı olma boyutu stres puanlarının anlamlı bir yordayıcısı değildir ( $\beta=-.07 ; p>.01)$. Diğer değişkenlerin etkisi kontrol edildiğinde, okul yöneticilerinin yaşadıkları stresin \%19'unun yönetsel güçlülükten kaynaklandığı söylenebilir. Yani, yöneticilerin yönetsel güçlülük düzeyleri arttıkça, yaşadıkları stresin azaldığı sonucuna ulaşılmaktadır.

Okul yöneticilerinin yönetsel güçlülük düzeylerinin, yaşadıkları depresyonun anlamlı bir yordayıcısı olup olmadığını belirlemek amacıyla yapılan çoklu regresyon analizi sonuçları Tablo 4'te verilmiştir. 
Tablo 4.

Okul Yöneticilerinin Yönetsel Güçlülük Düzeyleri, Demografik Özellikleri ve Depresyon Düzeyleri Arasındaki Iliş̧kiyi Gösteren Çoklu Regresyon Analizi Sonuçları

\begin{tabular}{|c|c|c|c|c|c|c|c|c|c|}
\hline $\begin{array}{l}\text { Yordayıcı } \\
\text { Değişkenler }\end{array}$ & $\mathbf{R}$ & $\mathbf{R 2}$ & $\begin{array}{c}\text { R2 } \\
\text { Değişikliği } \\
(\Delta \mathrm{R} 2) \\
\end{array}$ & $\begin{array}{c}F \\
\text { Değişikliği } \\
\text { P } \\
\end{array}$ & B & $\begin{array}{c}\text { Standart } \\
\text { Hata }\end{array}$ & B & $\mathbf{t}$ & $\mathbf{P}$ \\
\hline Standart & & & & & 9.639 & 2.681 & & 3.595 & .000 \\
\hline Adım 1 & .32 & .10 & .101 & .014 & & & & & \\
\hline Cinsiyet & & & & & 5.068 & 1.446 & .257 & 3.504 & .001 \\
\hline Medeni Durum & & & & & -.151 & 1.493 & -.007 & -.101 & .920 \\
\hline Görev & & & & & -.097 & .393 & -.018 & -.248 & .804 \\
\hline Atanma Şekli & & & & & -1.630 & 1.035 & -.112 & -1.574 & .117 \\
\hline Yaş & & & & & .004 & .053 & .008 & .081 & .936 \\
\hline Kidem & & & & & -.110 & .056 & -.198 & -1.961 & .051 \\
\hline Okulda çalışma süresi & & & & & -.005 & .007 & -.049 & -.683 & .495 \\
\hline Öğretmen sayısı & & & & & .024 & .027 & .126 & .889 & .375 \\
\hline Öğrenci sayısı & & & & & $6.652 \mathrm{E}-5$ & .001 & .007 & .049 & .961 \\
\hline Adım 2 & .56 & .31 & .212 & .000 & & & & & \\
\hline Görev odaklı olma & & & & & -.149 & .082 & -.127 & -1.809 & .072 \\
\hline $\begin{array}{l}\text { Temkinli ve tedbirli } \\
\text { olma }\end{array}$ & & & & & -.340 & .105 & -.216 & -3.243 & .001 \\
\hline Azimli olma & & & & & -.453 & .115 & -.282 & -3.927 & .000 \\
\hline
\end{tabular}

Tablo 4'teki veriler incelendiğinde, analize birinci adımda giren cinsiyet, medeni durum, görev, atanma şekli, yaş, kıdem, okuldaki çalışma süresi, öğretmen ve öğrenci sayıları değişkenlerinin birlikte depresyon ile anlamlı bir ilişki gösterdiği görülmektedir $(\Delta R 2=.101, p<.05)$. Ancak, regresyon katsayılarının anlamlılık düzeyleri incelendiğinde, sadece cinsiyet değişkeninin depresyonun anlamlı yordayıcısı olduğu $(\beta=-.26 ; p<.01)$, diğer değişkenlerin depresyonu açıklama gücüne sahip olmadığı görülmektedir. Analize ikinci adımda giren ve yönetsel güçlülüğün boyutlarının (görev odaklı olma, temkinli ve tedbirli olma ve azimli olma) depresyon puanlarının anlamlı yordayıcıları olduğu görülmektedir $(\triangle R 2=.21, p<.01)$. Ancak, regresyon katsayılarının anlamlılık düzeylerine bakıldığında temkinli ve tedbirli olma $(\beta=-.22, p<.01)$ ile azimli olma $(\beta=-.28, p<.01)$ değişkenlerinin, depresyon puanlarının anlamlı bir yordayıcısı olduğu anlaşılmaktadır. Bu bulgudan hareketle, okul yöneticilerinin depresyon düzeylerinin yaklaşık \%21'inin yönetsel güçlülük düzeyinden kaynaklandığı sonucuna ulaşılmaktadır. Yani, yöneticilerin yönetsel güçlülük algıları arttıkça, depresyon düzeyleri azalmaktadır. Okul yöneticilerinin yönetsel güçlülük düzeyleri yükseldikçe, yaşadıkları depresyon düzeyi azalmaktadır.

\section{Sonuç, Tartışma ve Öneriler}

Okul yöneticilerinin yönetsel güçlülük düzeyleri ile yaşadıkları stres ve depresyon arasındaki ilişkileri belirlemek amacıyla yapılan araştırmadan elde edilen bulgulara göre; hem yönetsel güçlülük toplam puanları hem de yönetsel güçlülügün görev odaklı olma, temkinli ve tedbirli olma ve azimli olma boyutlarının puanları ile stres ve depresyon puanları arasında istatistiksel olarak anlamlı ve ters yönlü ilişki tespit edilmiştir. Buna göre; okul yöneticilerinin yönetsel güçlülük düzeyleri arttıkça, stres ve depresyon düzeyleri azalmaktadır.

Yapılan çoklu regresyon analizinden elde edilen bulgulara göre; kişisel ve demografik değişkenler (cinsiyet, medeni durum, görev türü, atanma şekli, yaş, mesleki deneyim, okuldaki öğretmen sayısı, okuldaki öğrenci sayısı) kontrol edildikten sonra yönetsel güçlülüğün stres ve depresyonun anlamlı bir yordayıcısı olduğu ve yönetsel güçlülüğün, stres ve depresyon üzerindeki etkisinin önemli olduğu belirlenmiştir. Kanungo ve Menon (2004, 2005) tarafından yapılan çalışmalarda, yönetsel güçlülüğün psikolojik güçlendirmeyle pozitif yönde ve öğrenilmiş çaresizlikle negatif yönde anlamlı ilişkisinin olduğu ortaya konmuştur. Araştırmada elde edilen bulgular, yönetsel güçlülükle yakından ilişkisi olan öğrenilmiş 
güçlülük ve öğrenilmiş çaresizlik konusunda yapılan araştırma bulgularıyla paralellik göstermektedir (Yıldııım ve diğerleri, 2012; Akgün ve Ciarrochi, 2000; Chung ve diğerleri, 2012). Temelde yönetsel güçlülüğe benzeyen öğrenilmiş güçlülük, strese dayanıklıık açısından önem taşımaktadır. Çünkü konu ile ilgili yapılan çalışmalarda öğrenilmiş güçlülük, stres ile başa çıkma becerisi olarak bahsedilen bilişsel yapıyı oluşturmaktadır (Öztaykutlu, 2014). Öğrenilmiş güçlülük kavramını ilk kez ortaya atan Meichenbaum (1977) da öğrenilmiş güçlülüğün dış stres etmenleri ile başa çıkmanın yanı sıra sorunlu ve stresli yaşam olayları üzerinde de kontrolü sağlamak için bazı yardımcı tutumları içerdiğini belirtmiştir. Eroğlu, Akbaba, Adigüzel ve Peker (2014) tarafından yapılan çalışmada öğrenilmiş güçlülük ve stresle başa çıkma arasında anlamlı ilişkilerin olduğu görülmüştür. Yürür ve Keser (2010) çalışmalarında öğrenilmiş güçlülüğü, mesleki stresin yoğun olarak gerçekleştiği öğretmenlik mesleğindeki bireylerin kendi kendilerini stresten korunmalarını sağlayacak önemli bir kişisel özellik olduğunu ortaya koymuşlardır. Yine öğrenilmiş güçlülük için, Yıldırım ve diğerleri (2012) tarafından yapılan çalışmada öğrenilmiş güçlülüğün iki alt boyutu ile iş stresi alt boyutlarında baskı ve aşırı yüklenme arasında pozitif yönlü zayıf bir ilişki olduğu görülmüştür.

Araştırma bulgularına göre; yönetsel güçlülük ile, stres ve depresyon arasında anlamlı ilişkinin olduğu görülmüştür. Regresyon katsayılarının anlamlıık düzeyleri incelendiğinde temkinli ve tedbirli olma ile azimli olma değişkenlerinin, hem depresyon puanlarının hem de stres puanlarının anlamlı bir yordayıcısı olduğu görülmüştür. Yönetim süreçlerinin her aşamasında öncü rolü olan okul yöneticilerinin sergiledikleri başarılı performans, okuldaki işlerin yolunda gitmesi açısından önem arz etmektedir. İşin başarıla sonuçlanması da yöneticinin azimli ve kararlı bir şekilde süreci yönetebilmesiyle dolayısıyla yönetsel güçlülüğünün göstergesi olarak belirtilen (Kanungo ve Menon, 2004) teknik, problem çözme, karar verme, planlama, yönlendirme, kriz yönetme, iletişim, değişimi yönetme gibi birçok konudaki yeterliklerin varlığı ile ilişkili görülebilir. Örneğin birçok hususu dikkate alarak karar vermek zorunda olan ya da örgütsel kaynakların planlanması, örgütlenmesi, kontrolü görevlerinden birini gerçekleştirirken okul yöneticilerinin görev odaklı düşünmesi, verdikleri kararların diğerleri üzerindeki etkisini hesaba katması ve verdikleri kararları uygulamak konusunda azimli olmaları büyük önem taşımaktadır. Bu nedenle, okul liderlerinin bu süreçte zaman zaman stres yaşamaları ve depresif semptomlar göstermeleri olasıdır. Bu nedenle, yönetici seçimi ve atanmasında yönetsel güçlülük konusundaki yeterliklerin göz önünde bulundurulması doğru seçimler yapma hususunda önemli katkılar sağlayabilir.

Bu sonuçların ışığında şu önerilerde bulunmak mümkündür;

- Okul yöneticilerin yönetimsel davranışlarında bu denli önem arz eden bir konunun yöneticilerin seçiminde ve yetiştirilmesinde dikkate alınması faydalı olacaktır. Bilhassa son yıllarda yöneticilerin belirlenmesi sürecinde adayların sahip oldukları yönetsel güçleri belirli davranışlar dikkate alınarak değerlendirilmelidir. Ayrıca seçilen yöneticilerin görevlerinin ilk dönemlerinde olmak kaydıyla yönetsel güçlülük ile ilgili verilecek teori ile uygulamanın harmanlandığı eğitim ve seminerler de mutlaka yarar sağlayacaktır.

- Günümüz çalışma koşulları göz önüne alındığında stres ve depresif eğilimlerin varlığından uzak durmak bir bakıma imkânsız gibidir. Araştırmanın sonuçlarına göre stresin ve depresif eğilimlerin önlenmesi için yönetsel güçlülük düzeyinin artııımasının gerekliliği ortaya çıkmışıı. Dolayısıyla politika üretenlerin bu sonucu göz önünde bulundurarak okul yöneticilerinin çalışma şartlarında iyileştirmeler yapması yerinde olacaktır.

- Eğitim sistemimizin en önemli sorunlarından biri olan yönetici yetiştirme sürecinde; duyarlılık eğitimi gibi yöntemlerle, öğrenilmiş güçlülüğün ve dolayısıyla yönetsel güçlülüğün arttırılmasına çalışılmalıdır.

- Yönetsel güçlülük davranışının öncülü yahut sonucu sayılabilecek pek çok duygu durum, tutum ve davranış olabilir. Literatürden yola çıkıp, okul yöneticilerinin yönetsel güçlülüklerini etkileyebilecek duygu durum, tutum ve davranışları araştıılabilir ve bunlarla arasındaki ilişkileri ortaya koyan çalışmalar yapılabilir. 


\section{References}

Akgün, S., \& Ciarrochi, J. (2000). Learned resourcefulness moderates the relationship between academic stress and academic performance. Educational Psychology, 23(3), 287-294.

Aycan, Z. (1997). Expatriate adjustment as a multifaceted phenomenon: Individual and organizational level predictors. Journal of International Human Resource Management, 8(4), 434-456.

Baltaş, A., \& Baltaş, Z. (1998). Depresyon ve başa çıkma yolları. İstanbul: Remzi Bookstore.

Barutçugil, i. (2002). Performans yönetimi. İstanbul: Kariyer Publishing.

Büyüköztürk, Ş., Çakmak, E. K., Akgün, Ö. E., Karadeniz, Ş., \& Demirel, F. (2011). Bilimsel araştırma yöntemleri. Ankara: PegemA Publishing.

Chung C. C., Lin M. F., Ching Y. C., Kao C. C., Chou Y. Y., Ho P.H., \& Chang H. J. (2012). Mediating and moderating effects of learned resourcefulness on depressive symptoms and positive ideation in hospital nurses in Taiwan. Research in Nursing \& Health, 35(6), 576-588.

Creswell, J. W. (2012). Educational research: Planning, conducting, and evaluating quantitative (4th Ed.). New Jersey: Upper Saddle River.

Cüceloğlu, D. (1994). Insan ve davranışı. Psikolojinin temel kavramları. ìstanbul: Remzi Bookstore.

Doğan, S., \& Şahin, F. (2011). Yönetsel güçlülük ve etkililik: Kavramsal bir çalışma. Ataturk University Journal of Economics and Administrative Sciences (JEAS), 25(2), 61-85.

Eroglu, Y., Akbaba, S., Adigüzel, O., \& Peker, A. (2014). Learned resourcefulness and coping with stress in mothers of children with disabilities. Eurasian Journal of Educational Research, 55, 243-261.

Ersözlü, A. (2012). Okul yöneticilerinin yönetsel güçlülük düzeylerinin öğretmenlerin örgütsel bağlılık, örgütsel vatandaşlık davranışları ve iş doyumuna etkisi. Unpublished doctoral dissertation, Fırat University, Elazig.

Goldberg, L.R. (1999). A broad-bandwidth, public domain, personality inventory measuring the lowerlevel facets of several five-factor models. In I. Mervielde, I. Deary, F. De Fruyt \& F. Ostendorf (Eds.), Personality Psychology in Europe (pp. 7-28). Tilburg: Tilburg University Press.

Kanungo, R. N., \& Misra, S. (1992). Managerial resourcefulness: A reconceptualization of management skills. Human Relations, 45(12), 1311-1332.

Kanungo, R. N., \& Menon, T. (2004). Managerial resourcefulness: The construct and its measurement. Journal of Entrepreneurship, 13(2), 129-152.

Kanungo, R. N., \& Menon, S. T. (2005). Managerial resourcefulness measuring a critical component of leadership effectiveness. Journal of Entrepreneurship, 14(1), 39-55.

Karakuş, M. (2013). Emotional intelligence and negative feelings: A gender specific moderated mediation model. Educational Studies, 39(1), 68-82.

Karasar, N. (2008). Bilimsel araştırma yöntemi. Ankara: Nobel Publishing.

Meichenbaum, D. (1977). Cognitive-behavior modification. New York: Plenum.

Öztaykutlu, G. G. (2013). Investigation on pre-school teachers' learned resourcefulness and problem solving skills from different institutuions. Unpublished master's thesis. İstanbul Aydin University, istanbul

Sezer, S. (2011). Örgütsel depresyon ölçeğinin geliştirilmesi ve psikometrik niteliklerinin belirlenmesi. ISGUC The Journal of Industrial Relations and Human Resources, 13(1), 39-50.

Yıldırım, M. H., Gülpınar, Ş., \& Uğuz, Ş. (2012). iş yaşamında öğrenilmiş güçlülük ile iş stresi arasındaki ilişkileri belirlemeye yönelik bir araştırma. Journal of Organization and Management Sciences, 4(2), 133-144. 
Turhan, Kabatak, Şengür \& Zincirli - Çukurova Üniversitesi Eğitim Fakültesi Dergisi, 47(1), 2018, 216-232

Yürür, S., \& Keser, A. (2010). Öğrenilmiş güçlülüğün demografik değişkenlere bağlı olarak incelenmesi: Öğretmenler üzerine bir uygulama. Journal of Labour Relations, 1(1), 59-70. 